University of Nebraska - Lincoln

DigitalCommons@University of Nebraska - Lincoln

2006

\title{
Are trans-Pacific invasions the new wave?
}

Ragan M. Callaway

University of Montana

Shi Li Miao

South Florida Water Management District

Qinfeng Guo

U.S. Geological Survey

Follow this and additional works at: https://digitalcommons.unl.edu/usgsnpwrc

Part of the Other International and Area Studies Commons

Callaway, Ragan M.; Miao, Shi Li; and Guo, Qinfeng, "Are trans-Pacific invasions the new wave?" (2006). USGS Northern Prairie Wildlife Research Center. 20.

https://digitalcommons.unl.edu/usgsnpwrc/20

This Article is brought to you for free and open access by the US Geological Survey at DigitalCommons@University of Nebraska - Lincoln. It has been accepted for inclusion in USGS Northern Prairie Wildlife Research Center by an authorized administrator of DigitalCommons@University of Nebraska - Lincoln. 
Biological Invasions (2006) 8:1435-1437

DOI $10.1007 / \mathrm{s} 10530-005-5832-3$

\title{
Are trans-Pacific invasions the new wave?
}

\author{
Ragan M. Callaway ${ }^{1, *}$, Shi Li Miao ${ }^{2}$ \& Qinfeng Guo ${ }^{3}$ \\ ${ }^{1}$ Division of Biological Sciences, University of Montana, Missoula, MT, 59812, USA, ${ }^{2}$ South Florida Water \\ Management District, 3301 Gun Club Road, West Palm Beach, FL, 33406, USA; ${ }^{3}$ U.S. Geological Survey, \\ Northern Prairie WRC, 8711 37th St. SE, Jamestown, ND, 58401, USA; *Author for correspondence \\ (e-mail: ray.callaway@mos.umt.edu; fax: +1-406-243-4184)
}

Key words: Asia, exotic invasion, policy, prediction, regulation

The movement of organisms among continents by humans has caused profound changes in the ecology of relocated species and of communities to which they have been introduced. Perhaps less than $1 \%$ of all species that arrive at foreign shores become invaders (Williamson and Fitter 1996), but the few that explode in abundance wreak tremendous environmental and economic damage (Mack et al. 2000; Pimentel et al. 2000; $\mathrm{Xu}$ et al. 2006). During the last decade research on invasive species has dramatically increased. For example, from 1988 to 1990 the journal Ecology published three papers with the words 'invasive' or 'invader' in their title or abstract that related to exotics. From 1998 to 2000 this number increased to 14 . However, the focus of the increasing volume of research on exotic invaders has been primarily on the exchange of species between North America and Europe. Of the 14 papers on exotic invasions published in Ecology from 1998 to 2000, seven involved Europe-North America invasions and all primary empirical research focused on at least one species from Europe or North America. Two focused on a species moving to or from Asia and North America. The focus on North America and Europe may be driven by the unusually high numbers of organisms moved between these regions in the last few centuries (or to the unusually high numbers of ecologists), but regardless of why the historic focus has been on North America and Europe, future research on invasive species may shift to include those coming from and going to eastern Asia (Normile 2004).

As pointed out by Jenkins and Mooney (2006), trade between the United States and China has mushroomed from $\approx \$ 200$ million in 1978 to over $\$ 6$ billion in 2002. This increase in trade is highly likely to increase accidental invasions of organisms between North America and eastern Asia, a problem that will be difficult to solve. However, many invasive plant species appear to have been introduced intentionally for horticulture, agriculture, or forestry; and these invasions can be prevented by a farsighted and proactive policy. Increased trade is not the only reason for concern about new trans-Pacific invasions. The probability that the introduction of organisms will result in new invasions is exacerbated because eastern Asia and North America also have similar latitudes and climates and therefore share many biomes and taxa (Guo 2002).

Because rapidly growing trade between East Asia and North America also increases the probability of new trans-Pacific invasions, it is imperative to accelerate research designed to predict which species will invade and which ecosystems are vulnerable, to understand the mechanisms by which species transform into overwhelming competitive dominants, and to develop policy for 
preventing invasions and economic risk analysis for invasive species. This growing threat of exchanging invaders between eastern Asia and North America was addressed at the 2004 Beijing International Symposium on Biological Invasions titled 'Species Exchanges Between Eastern Asia and North America: Threats to Environment and Economy'. About 100 scientists from academia, governmental agencies, and other organizations from both regions focused on the current status of species exchange of trans-Pacific invasions (Liu et al. 2006; Xu et al. 2006; Kohli et al. 2006), predicting and preventing invasions (Erhenfeld 2006; Williamson 2006; Wu et al. 2006), eliminating invaders, understanding invasions (Alpert 2006; Guo 2006; Kitijami et al. 2006; Liu and Stiling 2006; Wang et al. 2006), and developing policy recommendations (Jenkins and Mooney, 2006) and management approaches (Gu 2006). This special feature was motivated, in part, by the outcome of the symposium. Although only a start, this special feature provides an initial model for international collaborations, information sharing (Simpson et al. 2006), and bilateral efforts to stem the increase in exotic invasions.

There were 283 invasive alien species in China including microorganisms, plants, invertebrates, amphibians, reptiles, fish, and mammals (Xu et al. 2006). Over $50 \%$ of these invasive species originated from North America (e.g., common ragweed, Ambrosia artemisiifolia and annual fleabane, Erigeron annuus). The total economic losses caused by invasive alien species to China were $\$ 14.45$ billion in 2000 , with direct and indirect economic losses accounting for 17 and 83\% of total economic losses, respectively. Yet, much more (ca. 800) plant species introduced from eastern Asia to North America have established, including the most notable invasives such as Chinese tallow (Sapium sebiferum), kudzu (Pueraria lobata), saltcedar (Tamarix chinensis), and two large carp species (Hypophthalmichthys molitrix and nobilis) that leap out of the Mississippi and Missouri rivers and injure boaters (Normile 2004).

Predicting future invasions has proved to be exceptionally difficult (Williamson 2006), but without some level of predictive ability, developing sound policy for restricting entry of particular species may be elusive. Classifying invaders by taxonomic relationships or by shared suite of traits has been helpful, but there are many exceptions to the rule, so many exceptions that prediction is quite inaccurate (Mack et al. 2000). In this feature, Williamson argues that looking for universal attributes and causes of invasions is not profitable, because invasions can go through a series of stages and the important factors are often different at each. When a cause has been found for a particular part of a set of invasions, it is important to distinguish between explanation (relatively easy) and prediction (much harder). Erhenfeld (2006) proposes that screening for novel plant secondary chemistry may be a useful predictive tool and collaborations among new groups of scientists may help us to predict new invasives.

Preventing invasions ultimately will be determined by policy makers. As argued by Mooney and Jenkins in this feature we are much better at determining whether a species proposed for import will invade. They suggest the adoption of a 'clean list' policy in which only approved species can be allowed to enter. As trade and transportation of species increases among the countries of North America and eastern Asia, we may have the opportunity to develop preemptive policy based on collaborative science between the regions rather than the retroactive responses once invasives have already established and spread.

Eliminating invaders may prove to be the most difficult, and in most cases perhaps, impossible task of all. The apparent permanence of many invasive species emphasizes the crucial necessity of good importation policies. Furthermore, rapid collaborative responses toward eradication of invaders must occur if we are to eliminate invaders before they become thoroughly naturalized. Again, explicit collaborative efforts among scientists in different continents, such as modeled in this feature, may allow much more rapid responses than in the past. Scientific responses may included the rapid development of herbicides, identification of host-specific and effective biological control agents (Ding et al. 2006), or simply a level of awareness promoting elimination of small populations before they spread.

Despite the fact that exotic invasions can result in astounding ecological changes, we do not 
know why they occur. The oldest and most widely accepted hypothesis is that invaders have escaped consumers, predators, herbivores, or pathogens that control them in their native habitat. But clear evidence for such escape from such powerful top-down regulation is scarce and invasions appear to have other causes such as response to human disturbance, occupation of empty niches, or the possession of novel biochemical weapons (Hierro et al. 2005; Kohli 2006). Relative to North America, the ecological and economic impact of exotics in eastern Asia is lower but on the rise ( $\mathrm{Li}$ and Wilcove 2005). One of the reasons for the Beijing symposium is that, although studies on invasives in China are relatively recent, some good progresses have been made. Therefore it is now feasible to make some meaningful comparisons in both research and invasives management between North America and eastern Asia. We hope that future collaborations among scientists in eastern Asia and North America, such as initiated in this special feature, will shed light on the nature of exotic invasions.

\section{References}

Alpert P (2006) The advantage and disadvantages of being introduced. Biological Invasions 8: 1523-1534

Ding JQ, Reardon R, Wu Y, Zheng H and Fu WD (2006) Biological control of invasive plants through collaboration between China and the United States of America: a perspective. Biological Invasions 8: 1439-1450

Ehrenfeld J (2006) A Potential novel source of information for screening and monitoring the impacts of exotic plants on ecosystems. Biological Invasions 8: 1511-1521

$\mathrm{Gu}$ B (2006) Environmental conditions and phosphorus removal in Florida lakes and wetlands inhabited by Hydrilla verticillata (Royle): implications for invasive species management. Biological Invasions 8: 1569-1578

Guo QF (2002) Perspectives on trans-Pacific biological invasions. Acta Phytoecologica Sinica 26: 724-730

Guo QF (2006) Intercontinental biotic invasions: what can we learn from native populations and habitats? Biological Invasions 8: 1451-1459

Hierro JL, Maron JL and Callaway RM (2005) A biogeographic approach to plant invasions: the importance of studying exotics in their introduced and native range. Journal of Ecology 93: 5-15

Jenkins PT and Mooney HA (2006) The United States, China, and invasive species: present status and future prospects. Biological Invasions 8: 1589-1593

Kitajima K, Fox AM, Sato T and Nagamatsu D (2006) Cultivar selection prior to introduction may increase invasiveness: evidence from Ardisia crenata. Biological Invasions 8: $1471-1482$

Kohli RK, Batish DR, Singh HP and Dogra KS (2006) Status, Invasiveness and Environmental threats of three tropical American invasive weeds (Parthenium hysterophorus L., Ageratum conyzoides L., Lantana camara L.) in India. Biological Invasions 8: 1501-1510

Li Y and Wilcove DS (2005) Threats to vertebrate species in China and the Unites States. BioScience 55: 147-153

Liu $\mathrm{H}$ and Stiling $\mathrm{P}$ (2006) Testing the enemy release hypothesis: a review and meta-analysis. Biological Invasions 8: 1535-1545

Liu J, Dong D, Miao SL, Li ZY, Song MH and Wang RQ (2006) Invasive alien plants in China: role of clonality and geographical origin. Biological Invasions 8: 1461-1470

Mack RN, Simberloff D, Lonsdale WM, Evans H, Clout M and Bazzaz FA (2000) Biotic invasions: causes, epidemiology, global consequences, and control. Ecological Applications 10: 689-710

Normile D (2004) Expanding trade with China creates ecological backlash. Science 306: 968-969

Pimentel D, Lach L, Zuniga R and Morrison D (2000) Environmental and economic costs of nonindigenous species in the United States. BioScience 50: 53-65

Simpson A, Sellers E, Grosse A and Xie Y (2006) Essential elements of online networks on invasive alien species. Biological Invasions 8: 1579-1587

Wang Q, Wang $\mathrm{CH}$, Zhao CH, Ma ZJ, Luo YQ, Chen JK and Li B (2006) Effects of growing conditions on the growth of and interactions between salt marsh plants: implications for invasibility of habitats. Biological Invasions 8: 1547-1560

Williamson M (2006) Explaining and predicting the success of invading species at different stages of invasion. Biological Invasions 8: 1561-1568

Williamson M and Fitter A (1996) The varying success of invaders. Ecology 77: 1661-1666

Wu YG, Rutchey K, Wang NM and Godin J (2006) The spatial pattern and dispersion of Lygodium microphyllum in the everglades wetland ecosystem. Biological Invasions 8: 1483 1493

$\mathrm{Xu}$ et al. (2006) The distribution and economic losses of alien species invasion to China. Biological Invasions 8: 1495 1500 